\title{
OPEN
}

Published online: 25 February 2020

\section{Author Correction: Demographic characteristics of free-roaming dogs (FRD) in rural and urban India following a photographic sight- resight survey}

\author{
Harish KumarTiwari, lan D. Robertson, Mark O’Dea \& Abi Tamim Vanak \\ Correction to: Scientific Reports https://doi.org/10.1038/s41598-019-52992-y, published online 12 November
} 2019

This Article contains errors in Reference 62 which was incorrectly given as:

Elly, H. \& Lex, H. Direct observation of dog density and composition during street counts as a resource efficient method of measuring variation in roaming dog population over time and between locations. Animals 7 , https:// doi.org/10.3390/ani7080057 (2017).

The correct reference is listed below as Reference 1:

\section{References}

1. Hiby, E. \& Hiby, L. Direct observation of dog density and composition during street counts as a resource efficient method of measuring variation in roaming dog population over time and between locations. Animals 7(8), 57, https://doi.org/10.3390/ ani7080057 (2017).

\begin{abstract}
(c) (i) Open Access This article is licensed under a Creative Commons Attribution 4.0 International c. License, which permits use, sharing, adaptation, distribution and reproduction in any medium or format, as long as you give appropriate credit to the original author(s) and the source, provide a link to the Creative Commons license, and indicate if changes were made. The images or other third party material in this article are included in the article's Creative Commons license, unless indicated otherwise in a credit line to the material. If material is not included in the article's Creative Commons license and your intended use is not permitted by statutory regulation or exceeds the permitted use, you will need to obtain permission directly from the copyright holder. To view a copy of this license, visit http://creativecommons.org/licenses/by/4.0/.
\end{abstract}

(C) The Author(s) 2020 